\title{
On stannic acid
}

\section{Fremy}

To cite this article: M. Fremy (1845) On stannic acid, Philosophical Magazine Series 3, 26:174, 456-457, DOI: $10.1080 / 14786444508645167$

To link to this article: http://dx.doi.org/10.1080/14786444508645167

$$
\text { 册 Published online: } 30 \text { Apr } 2009 .
$$

Submit your article to this journal

Џ Article views: 2

Q View related articles $\asymp$ 
so many of these huge animals become imbedded in this narrow space? Questions more easily asked than answered. My first conjecture, before seeing the place, was that they had been mired in attempting to reach a spring or lick; but the small extent and shallowness of the basin, and the gradual descent and character of its bottom, (which, as far as has been examined, is perfectly solid, and like much of the ground around, closely paved with rolled stones of gneiss and limestone, generally six or eight inches in diameter,) all forbid such a supposition. It is possible that they may have been swept there by a deluge, which, from the configuration of the surrounding country, would, as it subsided, sweep through the larger depression, with a current to the east, and form an eddy through this one to the west. The whole depression has, in form, a close resemblance to such as we see formed on a smaller scale in the sanci along the Delaware. But on the other hand, the number found together, most of them in a standing position, would seem rather to indicate that they had been overwhelmed in one of their native haunts, by some sudden catastrophe; and some circumstances seem to favour the supposition that this could not have been at a very remote period. This little basin receives the drainage of some fifteen acres of land, and seems to have had a considerable growth of grass and marsh plants around it. Under such circumstances, it would seem that the accumulation of vegetable matter indicates no very great antiquity. The holes were so filled with water that I could not ascertain whether the deposit below the sand showed anything like stratification, but as far as I could judge from what was thrown out, its character was pretty uniform throughout, exhibiting the appearance of a marsh much frequented by animals, which had trampled fragments of its plants all through it. I regretted very much that my knowledge was not sufficient to determine the species of the plants of which so many por. tions remain, but I thought I recognised some which are now growing in the neighbouring marshes, such as flags, cattails, \&c. I hope, however, that you or some of your scientific friends will visit the place, and obtain more accurate information than I am competent to give."

\section{ON STANNIC ACID. BY M. FREMY.}

'The author remarks that chemists have long considered the second degree of combination of tin with oxygen as a base susceptible of combining with acids to form salts : it is also well known that Guy. ton Morveau proposed to give this substance the name of stannic acid, in order to explain its solubility in the alkalies. M. Chevreul proved that it is a true acid, by showing that it reacted upon campeachy wood like an acid, whilst other metallic oxides, and even protoxide of tin, acted in this case like bases: the subject has since been considered by Berzelius and Gay-Lussac, and in 1835 Graham considered this peroxide as a base capable of combining with variable proportions of water, and forming with them different salts.

In the opinion of M. Fremy, peroxide of tin is in all cases to be 
considered as a true acid, and as incapable of combining with acids as a base to form salts.

The following are the reasons given by the author for adopting these opinions :-The action of peroxide of tin as an acid upon hematin, and on examining the compound which it forms with acids, no one of them possesses the properties of a salt; nitric acid dissolves but an inappreciable quantity; it combines with sulphuric acid, but the compound is decomposed by a few seconds' ebullition into sulphuric and stannic acids; and the same happens with the most distinctly marked metallic acids, as with antimonic acid: as to the compound of stannic with hydrochloric acid, may it not be compared to the chlorides of arsenic, sulphur, phosphorus and antimony, which have never been considered as true salts? Lastly, stannic acid does not combine with organic acids, or at any rate they form very unstable compounds, which are totally decomposed by water; under these circumstances M. Fremy is of opinion, that stannic acid combines with other acids to form double acids of little stability, like other compounds of this nature, instead of salts. Compounds of acids frequently occur in chemistry, and the complete decomposition of them which water effects is to a certain extent characteristic of them.

M. Fremy states an experiment, which in his opinion demonstrates positively that peroxide of tin is always an acid, even when separated from combination with hydrochloric acid :-if a solution of bichloride of tin be decomposed by carbonate of potash or soda, a precipitate is obtained, which is not peroxide of tin, but stannate of potash or of soda, which are insoluble in water containing a salt of potash; if, on the other hand, the bichloride of tin be treated with an insoluble carbonate, as that of lime or barytes, the stannic acid is then precipitated, possessing all the properties of an acid.-Ann. de Ch. et de Phys., Decembre 1844.

\section{METASTANNIC ACID.}

M. Fremy observes, that the experiments of Berzelius and his own show that there are two modifications of stannic acid which possess properties entirely different. One of these is prepared by precipitating bichloride of tin, as already stated, by an alkali or by carbonate of lime or barytes; and to this M. Fremy proposes to restrict the name of stannic acid, whilst for the acid prepared by acting upon the metal with nitric acid, he proposes the name of metastannic acid.

This is always formed as a hydrate, and M. Fremy found, that after drying it by a current of air at the usual temperature, taking the mean of three experiments, it contained 19.8 per cent. of water. Now, taking 58 as the equivalent of tin, and 74 as that of the binoxide, it is evident that a compound of one equivalent of the metastannic acid and two of water must contain $19 \cdot 5$ per cent. of water.

When hydrated metastannic acid is exposed to a temperature of $284^{\circ} \mathrm{Fahr}$., or to a vacuum, it loses very nearly 8 per cent. of water; if it parted with one equivalent, it would, of course, amount to $9 \cdot 7$. 